\title{
Efek Antihiperkolesterol dan Antihiperhgikemik Ekstrak Daun Ceremai (Phyllantus acidus (L.) Skeels) padaTikus Putih Jantan (Rattus norvegicus) Hiperkolesterol Diabetes
}

\section{(Antihypercholesterol and Antihyperglicemic Effect of Ceremai Leaf (Phyllantus acidus (L.) Skeels)Extract on Hypercholesterolemia Diabetes White Male Mice (Rattus norvegicus))}

\author{
Dermiati Tatto*, Niluh Puspita Dewi, Feiverin Tibe \\ Jurusan Farmasi, Sekolah Tinggi Ilmu Farmasi Pelita Mas, Palu, Indonesia
}

Article Info:

Received: 04 Mei 2017

in revised form: 24 Mei 2017

Accepted: 10 Juni 2017

Available Online: 01Oktober 2017

Keywords:

Phylantus acidus (L.) Skeels, antihyperglicemic,

antihypercholesterol,

hypercholesterolemia,

Diabetic mice

Corresponding Author:

Dermiati Tatto

Jurusan Farmasi, Sekolah Tinggi

Ilmu Farmasi Pelita Mas, Palu,

Indonesia

Phone : +62 812-4123-2252

Email: dermiatitatto@yahoo.co.id

\begin{abstract}
Ceremai (Phyllantus acidus (L.) Skeels is a plant that have been reported to possess antihyperglycemic and antihypercholesterol activity. This study aims to know the effect and effective dose of extract of ceremai leaves in decreasing of sugar blood level and cholesterol total on white male mice of hypercholesterolemia diabetes model induced by high lipid food and streptozotocin with $30 \mathrm{mg} / \mathrm{kg}$ BW dose. The study used 40 mice classified into 8 groups of treatments i.e normal control, simvastatin positive control, metformin positive control, negative control, and 4 treatment groups varied in concentration : $50 \mathrm{mg} / \mathrm{Kg} \mathrm{BW}, 100 \mathrm{mg} / \mathrm{Kg} \mathrm{BW}, 200 \mathrm{mg} / \mathrm{Kg} \mathrm{BW}$ and 400 $\mathrm{mg} / \mathrm{Kg} \mathrm{BW}$. Results showed that the extract of ceremai leaves had effect on both antihyperglicemic and antihypercholesterol on the white male mice of hypercholesterolemia diabetes model. Moreover, the effective dose of antihyperglycemic and antihypercholesterol was $200 \mathrm{mg} / \mathrm{KgBw}$.
\end{abstract}

Copyright $\odot 2017$ JFG-UNTAD This open access article is distributed under a Creative Commons Attribution (CC-BY-NC-SA) 4.0 International license.

How to cite (APA 6th Style):

Tatto D., Dewi NP., Tibe F. (2017). Efek Antihiperkolesterol dan Antihiperhgikemik Ekstrak Daun Ceremai (Phyllantus acidus (L.) Skeels) padaTikus Putih Jantan (Rattus norvegicus) Hiperkolesterol Diabetes. Jurnal Farmasi Galenika ( Galenika Journal of Pharmacy), 3(2), 157-164. doi:10.22487/j24428744.2017.v3.i2.8769 


\begin{abstract}
ABSTRAK
Daun Ceremai (Phyllantus acidus (L.) Skeels) merupakan tanaman yang telah banyak dilaporkan memiliki khasiat antihiperglikemik dan antihiperkolesterol. Penelitian ini bertujuan untuk mengetahui efek serta dosis efektif ekstrak daun ceremai dalam menurunkan kadar gula darah dan kolesterol total darah pada hewan uji tikus putih jantan model hiperkolesterolemia diabetes yang diinduksi pakan tinggi lemak dan streptozotocin dosis $30 \mathrm{mg} / \mathrm{kg}$ BB. Penelitian dilakukan menggunakan 40 ekor hewan uji yang dikelompokkan dalam 8 kelompok dengan perlakuan yaitu kelompok kontrol normal, kontrol positif simvastatin, kontrol positif metformin, kontrol negatif dan 4 kelompok uji dengan variasi dosis ekstrak masing-masing $50 \mathrm{mg} / \mathrm{kg} \mathrm{BB}, 100 \mathrm{mg} / \mathrm{kg} \mathrm{BB}, 200 \mathrm{mg} / \mathrm{kg}$ BB dan $400 \mathrm{mg} / \mathrm{kg}$ BB. Hasil yang diperoleh menunjukkan bahwa ekstrak daun ceremai memiliki efek antihiperglikemik dan antihiperkolesterol secara bersama-sama terhadap tikus putih jantan model hiperkolesterol diabetes dengan dosis efektif $200 \mathrm{mg} / \mathrm{kg} \mathrm{BB}$.
\end{abstract}

Kata Kunci : Phyllantus Acidus (L.) Skeels, antihiperglikemik, antihiperkolesterol, tikus hiperkolesterol diabetes

\section{PENDAHULUAN}

Indonesia merupakan negara tropis yang dikenal sebagai penghasil berbagai macam komoditas hasil pertanian termasuk diantaranya tanaman obat. Kondisi tanah yang subur, iklim yang baik serta didukung oleh keanekaragaman flora membuat Indonesia menjadi Negara penghasil komoditas obatobatan asal alam yang cukup potensial (Rahmi U dkk., 2013).

Hiperkolesterolemia adalah peningkatan kadar kolesterol dalam darah melebihi batas yang diperlukan oleh tubuh. Peningkatan kadar kolesterol dalam darah merupakan salah satu faktor penting dalam perkembangan penyakit arteri koroner yang sangat berperan terhadap gangguan kardiofaskular yang disebut aterosklerosis. Diabetes melitusadalah suatu penyakit kronis yang terjadi akibat pankreas tidak dapat memproduksi insulin dalam jumlah yang cukup atau ketika tubuh sudah tidak mampu lagi memberikan respon yang tepat terhadap insulin yang dihasilkan yang ditunjukkan dengan meningkatnya kadar glukosa dalam darah (hiperglikemia) (Rio,B.P., 2012).

Salah satu tanaman tradisional yang digunakan sebagai obat antihiperkolesterolemia dan diabetes adalah tanaman ceremai (Phyllantus acidus (L.) Skeels). Penelitian sebelumnya menyebutkan bahwa daun ceremai mengandung senyawa flavonoid, polifenol, dan saponin serta menunjukan bahwa ekstrak ceremai efektif menurunkan kadar kolesterol pada tikus pada dosis $22,5 \mathrm{mg} / \mathrm{KgBB}$ (Afifah B.S dkk., 2013). Penelitian tersebut kemudian didukung oleh beberapa penelitian selanjutnya yang menunjukan ekstrak daun ceremai dosis 250 $\mathrm{mg} / \mathrm{KgBB}$ memiliki efek hipolipidemia pada tikus putih jantan yang diinduksi streptozotocin(Chusri T et al., 2013).Penelitian lain menyatakan ekstrak etanol daun ceremai memiliki efek hipoglikemik pada dosis $200 \mathrm{mg} / \mathrm{KgBB}$ yang sebanding dengan glibenklamid (Aditi B dkk., 2015).

Penelitian ini merupakan penelitian lanjutan yang bertujuan mengetahui efekdan menentukan dosis ekstrak etanol daun ceremai terhadap penurunan kadarglukasa darah dan kadar kolesterol total darahpada tikushiperkolesterolemia diabetes dengan induksi pakan diet tinggi lemak dan streptozotocin. Penelitian ini diharapkan dapat memberikan informasi ilmiah kepada masyarakat tentang efektivitas daun ceremaisebagai antihiperkolesterol dan antihiperglikemik terutama pada penderita hiperkolesterolemia diabetik dan membantu bidang farmasi dalam memberikan pengobatan koplementer.

\section{METODE PENELITIAN}

Alat

Aluminium foil, Ayakan mesh 40, Batang pengaduk, Bejana maserasi, Blender (Panasonic), Cawan porselin, Erlemeyer(Pyrex), Gelas kimia (Pyrex), Gelas ukur(Pyrex), Glukometer (Easy Touch GCU), Glukotest strip test (Easy Touch GCU), Gunting, Kandang hewan uji, Labu Ukur(Pyrex), Mortir dan stamper, Penangas air, Pipet tetes, Rak tabung, Rotary Evaporator, Spoit injeki (Terumo Syringe), sonde/spoit oral (Terumo Syringe), Tabung reaksi, Timbangan analitik (Sartorius), Timbangan kasar.

\section{Bahan}

Air Suling, Aqua Pro Injeksi, Amoniak, Asam klorida pekat P, Asam Sulfat, Buffer sitrat saline 
(asam sitrat, $\mathrm{Na}$ sitrat), Etanol 96\%, Kloroform, Larutan $\mathrm{FeCl}_{3}$, Larutan $\mathrm{NaCl10 \%}$, Na-CMC, Pakan diet tinggi lemak (pakan standar, lemak kambing, kuning telur), Pereaksi Dragendorff, Pereaksi Lieberman-Bunchard, Pereaksi Meyer, Pereaksi Wagner, Serbuk Magnesium P, Simplisia daun ceremai (Phyllantus acidum (L.) Skeels), Stik Glukosa (Easy Touch GCU), Stik kolesterol (Easy Touch GCU), Streptozotocin (Bioworld USA), Tablet Metformin, dan Tablet Simvastatin.

\section{Metode \\ Pengambilan dan Pengolahan Bahan Uji}

Bahan yang digunakan adalah daun ceremai (Phyllantus acidum (L.) Skeels) yang diperoleh dari kota Palu dalam bentuk daun segar berwarna hijau yang diolah menjadi serbuk simpisia.

\section{Pembuatan Ekstrak Etanol Daun Ceremai}

Pembuatan ekstrak daun daun ceremai (Phyllantus acidum (L.) Skeels) dilakukan dengan menggunakan metode maserasi menggunakan pelarut etanol $96 \%$.

\section{Uji Penapisan Fitokimia}

Penapisan fitokimia dilakukan untuk mendeteksi adanya metabolit sekunder berdasarkan golongannya dan sebagai informasi awal untuk mengetahui golongan senyawa kimia yang mempunyai aktivitas biologis dari suatu tanaman dalam bentuk simplisia atau ekstrak. Pengujian dilakukan terhadap golongan senyawa alkaloid, flavonoid, polifenol, saponin, dan tanin yang dilakukan secara kualitatif dengan reaksi warna atau pengendapan.

\section{Penyiapan Hewan Uji}

Tikus wistar sebanyak 40 ekor diadaptasikan selama dua minggu di laboratorium dengan dikandangkan secara memadai pada suhu lingkungan normal dan diberikan pakan standar serta minum. Hewan uji dibagi secara acak dalam 8 kelompok, yaitu kelompok normal, kelompok kontrol negatif,kelompok kontrol positif metformin, kelompok positif simvastatin, dan 4 kelompok perlakuan dengan dosis yang berbeda yaitu 50 $\mathrm{mg} / \mathrm{kgBB}, 100 \mathrm{mg} / \mathrm{kgBB}, 200 \mathrm{mg} / \mathrm{KgBB}$ dan 400 $\mathrm{mg} / \mathrm{kgBB}$, masing-masing satu kelompok terdiri dari 5 ekor hewan uji.

\section{Pembuatan Pakan Diet Tinggi Lemak}

Makanan tinggi lemak yang digunakan adalah pakan standar (80\%), lemak kambing (15\%) dan kuning telur bebek (5\%). Pakan dibuat dengan cara memanaskan lemak kambing dengan cara melelehkan hingga lemak kambing menjadi minyak. Telur direbus hingga matang, dipisahkan kuning telur dengan putih telur. Kuning telur dikeringkan dalam oven selama kurang lebih 24 jam kemudian digerus hingga halus. Pakan standar digerus sampai halus lalu dicampurkan dengan kuning telur dan minyak lemak kambing. Campuran diaduk sampai homogen kemudian dibentuk menjadi pellet. Jumlah konsumsi makanan setiap harinya maksimum sebanyak 20 g/tikus dan diberikan selama 4 minggu.

\section{Pembuatan Larutan Streptozotocin}

Streptozotocin (STZ) 0,24 gram dilarutkan ke dalambuffer sitrat $\mathrm{pH}$ 4,5 hingga $100 \mathrm{ml}$, selanjutnya divortex hingga homogen, sehingga dihasilkan larutan STZ stok. Larutan STZ stok disimpan pada suhu $4^{\circ} \mathrm{C}$

PembuatanModel Tikus yang DiinduksiPakan Diet Tinggi Lemak, Injeksi Streptozotocin DosisRendah dan Pengujian Ekstrak

Tikus diberi pakan standar yang terdiri dari12\% lemak, $60 \%$ karbohidrat, dan $28 \%$ protein selama 14 hari kemudian dilakukan pengukuran kadar glukosa darah dan kadar kolesterol awal. Kemudian diberi pakan diet tinggi lemak high fat dietdengan komposisi pakan (80\%), lemak kambing $(15 \%)$, dan kuning telur bebek (5\%). Jumlah kelompok hewan uji yang mendapatkan pakan tinggi lemak sebanyak 7 kelompok dan 1 kelompok normal hanya diberikan suspensi $\mathrm{Na}$ CMC $0,5 \%$ (tidak diberikan induksi pakan tinggi lemak dan streptozotocin). Empat minggu setelah pemberian pakan tinggi lemak, tikus ditimbang berat badan dengan tujuan untuk melihat tikus dalam keadaan obesitas, setelah itu tikus dipuasakan semalam (16 jam), hewan kemudian dinjeksikan dengan streptozotocin dosis rendah $(30 \mathrm{mg} / \mathrm{kg}$ berat badan dalam citrate-buffered saline, $\mathrm{pH}$ 4.5) secara intraperitonial. Setelah 1 minggu diukur kadar glukosa darah puasa dan kadar kolesterol total darah puasa setelah induksi. Diberi perlakuan secaraper oral sesuai dengan kelompoknya selama 2 minggu. Kontrol negatif (K-) diberi suspensi Na CMC 0,5\%, untuk kelompok kontrol positif metformin $(\mathrm{K}+)$ diberi suspensi metformin, kelompok kontrol positif simvastatin $(\mathrm{K}++)$ diberi suspensi simvastatin dan 
untuk kelompok uji diberi ekstrak kental daun ceremaidengan dosis masing-masing 50 $\mathrm{mg} / \mathrm{kgBB}, 100 \mathrm{mg} / \mathrm{kgBB}, 200 \mathrm{mg} / \mathrm{KgBB}$ dan400 $\mathrm{mg} / \mathrm{kgBB}$. Kemudian kadar glukosa darah dan kolesterol total darah diperiksa pada hari ke 42 (hari ke 7 setelah perlakuan) dan hari ke 49(hari ke 14 setelah perlakuan). Semua sampel darah diambil dari vena ekor tikus, pengukuran kadar glukosa darah dan kadar kolesterol total darah diukur dengan alat glukometer dan cholestest.

\section{Penentuan Kadar Glukosa Darah}

Masingmasing tikus diambil sampel darah dari vena ekor dan diukur kadar glukosa dan kolesterol total darahnya dengan menggunakan alat glukometer dan cholestest.

\section{Analisis Data}

Data yang diperoleh berupa hasil penurunan kadar gula darah dan kadar kolesterol total dianalisis menggunakan uji statistik One Way Anova dengan taraf kepercayaan $95 \%$. Jika terdapat perbedaan yang signifikan, maka dilakukan uji lanjutPost Hoc Duncan untuk mengetahui kelompok perlakuan yang berbeda signifikan dibandingkan kelompok perlakuan lainnya. Pengolahan data dilakukan menggunakan program Software SPSS 20.0

\section{HASIL DAN PEMBAHASAN}

Penelitian ini menggunakan daun ceremai(Phyllantus acidus (L.) Skeels) yang diperoleh dari daerah kota Palu Provinsi Sulawesi Tengah berupa bentuk daun segar yang kemudian dioleh menjadi serbuk simplisia kering. Identifikasi tanaman dilakukan di UPT Sumber Daya Hayati Universitas Tadulako. Hasil identifikasi membuktikan bahwa daun ceremai yang digunakan adalah species Phyllantus acidus (L.) Skeels. Ekstrak kental diperoleh dari proses ekstraksi maserasi yang dipilih dengan pertimbangan sifat daun yang lunak dan mudah mengembang dalam cairan pengekstraksi. Metode masetasi diharapkan akan melarutkan zat aktif akibat adanya perbedaan konsentrasi antara larutan zat aktif di dalam dengan di luar sel menyebabkan larutan yang terpekat keluar hingga terjadi keseimbangan konsentrasi antara larutan di dalam dengan di luar sel.

Cairan penyari yang digunakan adalah etanol 96\%. Etanol dipertimbangkan sebagai cairan penyari karena lebih selektif, kapang sulit tumbuh dalam etanol $20 \%$ ke atas, tidak beracun, netral, absorbsinya baik, etanol dapat bercampur dengan air dalam segala perbandingan, memerlukan panas yang lebih sedikit untuk proses pemekatan, dan zat pengganggu yang larut terbatas. Etanol bersifat semipolar yang dapat melarutkan bahan aktif yang terkandung di dalam tanaman, baik yang bersifat polar, nonpolar dan semipolar, etanol juga diketahui lebih aman (tidak bersifat toksik). Ekstrak kental yang diperoleh dari hasil maserasi simplisia daun ceremai yaitu42gram dengan nilai rendemen yang diperoleh adalah $8,4 \%$.

Hasil uji fitokimia pada menunjukkan bahwa ekstrak daun ceremai (Phyllantus acidus (L.) Skeels) mengandung alkaloid, flavonoid, polifenol, saponin dan tanin. Hal ini sesuai dengan penelitian Afifah, 2013 yang menyatakan bahwa daun ceremai mengandung saponin, flavonoid, polifenol, tanin.

Tabel 1. Hasil uji penapisan fitokimia

\begin{tabular}{cll}
\hline Pengujian & \multicolumn{1}{c}{ Hasil Pengamatan } & Hasil \\
\hline Alkaloid & Warna merah jingga & Positif \\
Flavonoid & Warna kuning jingga & Positif \\
Polifenol & Warna biru & Positif \\
Saponin & Terbentuk busa stabil dan tidak hilang & Positif \\
Tanin & seketika setelah ditetesi asam klorida N & Parna biru kehitaman \\
\hline
\end{tabular}

\section{Hasil Pengukuran Kadar Glukosa Darah dan Kolesterol Total Darah}

Penelitian menggunakan hewan uji berupa tikus putih jantan (Rattus norvegicus) sebanyak 40 ekor,sebelum digunakansemua kelompok tikus dipuasakan selama 16 jam untuk pengukuran kadar glukosa darah dan kadar kolesterol total awal pada hewan uji agar memastikan bahwa hewan uji tersebut mempunyai kadar glukosa darah dan kolesterol total yang normal yaitu $50-135 \mathrm{mg} / \mathrm{dL}$ dan $<200 \mathrm{mg} / \mathrm{dL}$. Hasil pengukuran kadar glukosa awal dan kolesterol total awal (Tabel 2 dan Tabel 3) menunjukkan tikus dalam keadaan normal/sehat. Selanjutnya tikus diberi makanan pakan diet tinggi lemak dengan komposisi pakan (80\%), lemak kambing (15\%), dan kuning telur bebek (5\%) selama 4 minggu, kecuali kelompok 
sehat tetap diberi makanan pakan standar. Tujuan pemberian pakan diet tinggi lemak tikus dibuat obesitas dan juga diharapkan dapat meningkatkan kandungan asam lemak bebas didalam plasma sel yang mengakibatkan penurunan sensitivitas insulin pada jaringan perifer.

Tabel 2. Selisih penurunan kadar glukosa darah pada hewan uji

\begin{tabular}{|c|c|c|c|}
\hline \multirow{2}{*}{ Kelompok Perlakuan } & \multirow[t]{2}{*}{ No } & \multicolumn{2}{|c|}{ Selisih penurunan kadar glukosa darah (mg/dL) } \\
\hline & & KGDI - KGDP42 & KGDI- KGDP49 \\
\hline \multirow{5}{*}{$\begin{array}{c}\text { Kontrol (-) } \\
\text { Suspensi Na-CMC } \\
0,5 \%\end{array}$} & 1 & 53 & 64 \\
\hline & 2 & 48 & 110 \\
\hline & 3 & 90 & 11 \\
\hline & 4 & 141 & 295 \\
\hline & 5 & 251 & 332 \\
\hline Rerata \pm SD & & $116,6^{\mathrm{a}} \pm 83,8$ & $162,4^{\mathrm{a}} \pm 142,9$ \\
\hline \multirow{5}{*}{$\begin{array}{c}\text { Kontrol (+) } \\
\text { Suspensi metformin }\end{array}$} & 1 & 282 & 288 \\
\hline & 2 & 347 & 320 \\
\hline & 3 & 297 & 330 \\
\hline & 4 & 355 & 393 \\
\hline & 5 & 191 & 205 \\
\hline Rerata \pm SD & & $294,4^{\mathrm{bc}} \pm 65,7$ & $307,2^{b} \pm 68,6$ \\
\hline \multirow{5}{*}{$\begin{array}{l}\text { Ekstrak Etanol Daun } \\
\text { Ceremai50 mg/kgBB }\end{array}$} & 1 & 501 & 520 \\
\hline & 2 & 319 & 535 \\
\hline & 3 & 467 & 457 \\
\hline & 4 & 319 & 348 \\
\hline & 5 & 467 & 510 \\
\hline Rerata \pm SD & & $414,6^{\mathrm{d}} \pm 88,3$ & $437,6^{\mathrm{d}} \pm 83,0$ \\
\hline \multirow{5}{*}{$\begin{array}{c}\text { Ekstrak Etanol Daun } \\
\text { Ceremai100 mg/kgBB }\end{array}$} & 1 & 340 & 350 \\
\hline & 2 & 296 & 294 \\
\hline & 3 & 409 & 423 \\
\hline & 4 & 357 & 368 \\
\hline & 5 & 452 & 452 \\
\hline Rerata \pm SD & & $370,8^{\mathrm{cd}} \pm 60,8$ & $377,4^{\mathrm{bc}} \pm 62,1$ \\
\hline \multirow{5}{*}{$\begin{array}{c}\text { Ekstrak Etanol Daun } \\
\text { Ceremai200 mg/kgBB }\end{array}$} & 1 & 191 & 221 \\
\hline & 2 & 303 & 322 \\
\hline & 3 & 448 & 444 \\
\hline & 4 & 307 & 310 \\
\hline & 5 & 446 & 481 \\
\hline Rerata \pm SD & & $339^{\text {cd }} \pm 109,3$ & $377,4^{\mathrm{bc}} \pm 105,9$ \\
\hline \multirow{5}{*}{$\begin{array}{c}\text { Ekstrak Etanol Daun } \\
\text { Ceremai400 mg/kgBB }\end{array}$} & 1 & 171 & 182 \\
\hline & 2 & 237 & 263 \\
\hline & 3 & 262 & 288 \\
\hline & 4 & 221 & 269 \\
\hline & 5 & 183 & 256 \\
\hline Rerata \pm SD & & $214,8^{\mathrm{ab}} \pm 37,7$ & $251,6^{\mathrm{ab}} \pm 40,6$ \\
\hline
\end{tabular}


Tabel 3. Selisih penurunan kadar kolesterol total darah pada hewan uji

\begin{tabular}{|c|c|c|}
\hline \multirow{2}{*}{$\begin{array}{l}\text { Kelompok } \\
\text { Perlakuan }\end{array}$} & \multicolumn{2}{|c|}{ Selisih penurunan kadar kolesterol total darah $(\mathrm{mg} / \mathrm{dL})$} \\
\hline & KKTDI - KKTD P42 & KKTDI - KKTD P49 \\
\hline \multirow{5}{*}{$\begin{array}{c}\text { Kontrol (-) } \\
\text { Suspensi Na-CMC } \\
0,5 \%\end{array}$} & 132 & 129 \\
\hline & 370 & 355 \\
\hline & 206 & 207 \\
\hline & 185 & 171 \\
\hline & 190 & 188 \\
\hline Rerata \pm SD & $216,6^{\mathrm{d}} \pm 90,1$ & $210,0^{\mathrm{d}} \pm 86,0$ \\
\hline \multirow{5}{*}{$\begin{array}{c}\text { Kontrol (+) } \\
\text { Suspensi } \\
\text { Simvastatin }\end{array}$} & 192 & 189 \\
\hline & 220 & 205 \\
\hline & 96 & 97 \\
\hline & 106 & 92 \\
\hline & 122 & 120 \\
\hline Rerata \pm SD & $147,2^{\mathrm{bc}} \pm 55,3$ & $140,6^{\mathrm{bc}} \pm 52,8$ \\
\hline \multirow{5}{*}{$\begin{array}{c}\text { Ekstrak Etanol } \\
\text { Daun Ceremai50 } \\
\text { mg/kgBB }\end{array}$} & 28 & 205 \\
\hline & 25 & 50 \\
\hline & 14 & 44 \\
\hline & 14 & 84 \\
\hline & 20 & 51 \\
\hline Rerata \pm SD & $20,2^{a} \pm 6,3$ & $86,8^{\mathrm{a}} \pm 67,9$ \\
\hline \multirow{5}{*}{$\begin{array}{c}\text { Ekstrak Etanol } \\
\text { Daun Ceremai100 } \\
\text { mg/kgBB }\end{array}$} & 71 & 85 \\
\hline & 158 & 124 \\
\hline & 324 & 272 \\
\hline & 288 & 245 \\
\hline & 138 & 120 \\
\hline Rerata \pm SD & $195,8^{\mathrm{c}} \pm 106,3$ & $169,2^{b c} \pm 83,4$ \\
\hline \multirow{5}{*}{$\begin{array}{c}\text { Ekstrak Etanol } \\
\text { Daun Ceremai200 } \\
\text { mg/kgBB }\end{array}$} & 253 & 215 \\
\hline & 146 & 137 \\
\hline & 101 & 90 \\
\hline & 314 & 305 \\
\hline & 88 & 80 \\
\hline Rerata \pm SD & $180,4^{\mathrm{bc}} \pm 98,9$ & $165,4^{\mathrm{bc}} \pm 94,5$ \\
\hline \multirow{5}{*}{$\begin{array}{c}\text { Ekstrak Etanol } \\
\text { Daun Ceremai400 } \\
\text { mg/kgBB }\end{array}$} & 88 & 82 \\
\hline & 73 & 83 \\
\hline & 66 & 69 \\
\hline & 82 & 91 \\
\hline & 94 & 111 \\
\hline Rerata \pm SD & $80,6^{\mathrm{ab}} \pm 11,2$ & $87,2^{\mathrm{a}} \pm 15,4$ \\
\hline
\end{tabular}

Setelah pemberian pakan diet tinggi lemak, dilanjutkan dengan induksi streptozotocin dengan dosis $30 \mathrm{mg} / \mathrm{kg}$ BB secara intraperitoneal. Streptozotocin (STZ) sering digunakan sebagai induksi insulin-dependent dan non-insulin-dependent diabetes melitus pada hewan uji karena selektif merusak sel beta pankreas. STZ bekerja langsung pada sel beta pankreas dengan aksi sitotoksinya dimediatori oleh reactive oxygen species (ROS) sehingga dapat digunakan sebagai induksi diabetes melitus. STZ sebagai agen diabetonik dapat memicu peningkatan produksi radikal bebas berlebih dan menyebabkan stres oksidatif (Lestari., 1997). 
Pengukuran kadar kolesterol pada tikus setelah induksi pakan diet tinggi lemak dan streptozotocin juga menunjukkan adanya peningkatan kadar kolesterol dibandingkan kadar kolesterol awal. Hal ini berarti bahwa induksi pakan diet tinggi lemak dan streptozotocin dapat meningkatkan kadar kolesterol dan kadar glukosa darah secara signifikan. Hasil induksi menunjukkan adanya peningkatan kadar glukosa darah tikus yang signifikan yang berkisar 300 sampai600 $\mathrm{mg} / \mathrm{dL}$ dan peningkatan kadar kolesterol total darah dengan kisaran 250 sampai 550 $\mathrm{mg} / \mathrm{dL}$.

Hasil uji statistik One Way Anova pada selisih penurunan kadar glukosa darah kelompok hewan uji pada hari ke-42 dan ke-49 memperlihatkan nilai signifikansi $p=0,000 \quad(p<0,05)$ yang menunjukkan nilai $p$ lebih kecil dari 0,05 yang menunjukkan terdapat perbedaan yang signifikan dari semua perlakuan pada hari ke-42 dan 49. Uji dilanjutkan dengan uji lanjut Post Hoc Duncan untuk melihat perbedaan yang bermakna pada kelompok perlakuan. Hasil uji statistik One Way Anova pada selisih penurunan kadar kolesterol total darah kelompok hewan uji pada hari ke-42 memperlihatkannilai signifikansi $p=0,000 \quad(p<0,05)$ yang menunjukkan nilai $p$ lebih kecil dari 0,05 yang menunjukkan terdapat perbedaan yang signifikan dari semua perlakuan pada hari ke-42. Uji dilanjutkan dengan uji lanjut Post Hoc Duncan untuk melihat perbedaan yang bermakna pada kelompok perlakuan

Hasil pengujian Post Hoc Duncan, selisih penurunan kadar glukosa darah pada hari ke 42 dan 49 menunjukkan perbedaan yang signifikan antara kelompok kontrol negatif yang diberikan suspensi $\mathrm{Na}$ CMC $0,5 \%$ dengan kelompok kontrol positif metformin dan keempat variasi dosis ekstrak daun ceremai. Hal ini menunjukkan keempat variasi dosis ekstrak daun ceremaidapat menurunkan kadar gula darah tikus putih, namun pada hari ke 49 dapat ditentukan bahwa ekstrak etanol daun ceremai pada dosis $200 \mathrm{mg} / \mathrm{KgBB}$ memperlihatkan efek yang setara dengan kontrol positif metformin merupakan zat antihiperglikemik oral golongan biaguanid yang memiliki efek menurunkan kadar glukosa darah dan mekanisme kerjanya yaitu metformin mampu menambah sensitivitas terhadap insulin dan menekan produksi glukosa hati sehingga kadar glukosa dalam darah menurun dan secara tidak langsung mengurangi pembentukan senyawa oksigen reaktif akibat hiperglikemia.

Hasil pengujian Post Hoc Duncanselisih penurunan kadar kolesterol total darah pada hari ke
42 dan 49 menunjukkan perbedaan yang signifikan antara kelompok kontrol negatif yang diberikan suspensi $\mathrm{Na} \mathrm{CMC}$ 0,5\% dengan kelompok kontrol positif simvastatin dan keempat variasi dosis ekstrak daun ceremai. Hal ini menunjukkan keempat variasi dosis ekstrak daun ceremaidapat menurunkan kadar gula darah tikus putih, namun dapat ditentukan bahwa ekstrak etanol daun ceremai pada dosis 200 $\mathrm{mg} / \mathrm{KgBB}$ memperlihatkan efek yang setara dengan kontrol positif simvastatin.

Efek antihiperkolesterolemia diabetes ekstrak daun ceremai disebabkan adanya kandungan senyawa alkaloid yang berefek pada meningkatnya sekresi insulin. Insulin yang terproduksi kembali akan menghambat Lipase Sensitive Hormone (LSH). Penghambatan LSH menyebabkan terhentinya hidrolisis lemak dan pengubahan asam lemak menjadi fosfolipid dan kolesterol. Flavonoid yang bekerja secara maksimal sebagai antioksidan, flavoloid diketahui dapat menurunkan kadar kolesterol total dengan mekanisme menghambat aktivitas enzim MHG $\mathrm{KoH}$ reduktase yang berperan penting dalam biosintesis kolesterol (Olivera $\mathrm{T}$ et al). Flavonoid juga dapat bertindak sebagai kofaktor enzim kolesterol esterase dan inhibitor absorbsi kolesterol makanan dengan menghambat pembentukan misel sehingga penyerapan kolesterol terhambat. Tanin diketahui dapat memacu metabolisme glukosa dan lemak sehingga timbunan kedua sumber kalori ini dalam darah dapat dihindari. Selain itu tanin juga berfungsi sebaga adstrigent atau pengkhelat yang dapat mengerutkan membran epitel usus halus sehingga mengurangi penyerapan sari makanan dan sebagai akibat menghambat asupan glukosa dan lemak serta laju peningkatan glukosa dan kolesterol darah tidak terlalu tinggi (Prameswarih, O.M et al., 2014). Penurunan stress oksidatif secara umum dapat mengurangi resistensi insulin dan menghambat kerusakan sel $\beta$ pankreas, sehingga polifenol terindikasi mampu menahan resiko penyakit diabetes melitus berkembang menjadi lebih parah (Ridwan A dkk., 2012).

\section{KESIMPULAN}

Berdasarkan hasil penelitian, dapat disimpulkan bahwa ekstrak daun ceremai ((Phyllantus acidus (L.) Skeels) memiliki efek antihiperglikemik dan antihiperkolesterol pada tikus putih jantan (Rattus norvegicus) model hiperkolesterolemia diabetes. Ekstrak daun ceremai ((Phyllantus acidus (L.) Skeels) pada dosis $200 \mathrm{mg} / \mathrm{kg}$ BB paling efektif menurunkan kadar glukosa darah dan kadar 
kolesterol total tikus putih jantan (Rattus norvegicus) hiperkolesterolemia diabetes sebanding dengan kontrol positif metformindan simvastatin.

\section{UCAPAN TERIMAKASIH}

Penulis mengucapkan terima kasih kepada Yayasan Pelita Mas Palu dan Sekolah Tinggi Ilmu Farmasi yang telah memberikan dukungan dalam pendanaan penelitian ini. Kepada seluruh tim yang terdiri dari dosen serta bantuan dari mahasiswa atas dukungan dan kerjasama sehingga penelitian ini dapat terlaksana dengan baik.

\section{DAFTAR PUSTAKA}

Rahmi U., Manjang Y., Santoni A. (2013). Profil fitokimia metabolit sekunder dan uji aktifitas antioksidan tanaman jeruk purut (Citrus histrix DC) dan jeruk bali (Citrus Maxima (Burm.f) Merr). Jurnal Kimia Universitas Andalas. Vol.2 No.2. Padang.

Rio, B.P. (2012). Efek hipoglikemik kombinasi ekstrak metanol-Air daun macaranga Tanarius L. denganinsulin pada tikus wistar jantan terbebani glukosa. (Skripsi) Universitas Fakultas Farmasi Sanata Dharma. Yogyakarta.

Afifah B.S., Elin Y.S. (2013). Efek antikolesterol ekstrak etanol daun ceremai (Phylantus acidus (L.) Skeels) pada tikus putih betina. (Skripsi) Fakultas Farmasi Universitas Jendral Ahmad Yani. Bandung.

Chusri T. (2013). Hypoglycemic and hypolipidemia properties of leaf extract from Phyllantus acidum (L.) Skeels, laucaena leucocephala (Lam) de Wit and Psidium guajava (L.) in streptozotocin induced diabetic rat. International Journal of Biosciences. Vol 2 No.2.

Aditi B.(2015). Hepatoprotective and hypoglycemic activity of Phyllantus acidus leaf extract in wistar albino rats. International Journal of Universal Pharmacy and Biosciences. Vol 4 No 1.

Lestari. K.(1997). Uji aktivitas antihiperlipidemia daun jati belanda (Guazuma ulmifolia) pada tikus. Laporan Penelitian. Universitas Padjajaran. Bandung.

Olivera T., Ricardo, K.F.S., et al. Hypolipidemic effect of flavonoids and cholestiramine in rats tania. Latin American Journal of Pharmacy.

Prameswarih, O.M., Widjanarko S.B. (2014). Uji efek ekstrak daun pandan wangi terhadap kadar glukosa darah dan histologi tikus diabetes melitus. Jurnal Pangan dan Agroindustri. Vol. 02 No. 02. Universitas Brawijaya. Malang.

Ridwan A., Astrian R.T., Barlian A. (2012). Pengukuran efek antidiabetes polifenol (Polifenol 60) berdasarkan kadar glukosa darah dan histologi pankreas mencit (Mus musculus L.) jantan yang dikondisikan diabetes melitus. Jurnal Matematika dan Sains. Vol. 17 No. 02. Institut Teknologi Bandung. Bandung. 